International Journal of Engineering \& Technology, $7(2.13)(2018) 442-446$
International Journal of Engineering \& Technology
SPC
Website: www.sciencepubco.com/index.php/IJET
Research Paper

\title{
Development of Indonesian Literature Textbook with Character Education Through Information and Communication Technology (ICT) Learning Based
}

\author{
Retno Winarni*, St. Y. Slamet, Kundharu Saddhono \\ Universitas Sebelas Maret, Surakarta, Indonesia \\ *Corresponding author E-mail: retnowinarni@staff.uns.ac.id
}

\begin{abstract}
The objectives of this research were: (1) to describe the students' and teachers' needs on Indonesian literature textbook with characteristic education using ICT learning based, (2) to describe the development of Indonesian literature textbook model using ICT learning based, (3) to describe the effectiveness of the textbook using ICT learning based, 4) to describe the result of textbook dissemination using ICT learning based. The type of research used was research and development proposed by Borg and Gall. Research which was done through 4 stages, namely: (1) exploration, (2) model development, (3) model testing, and (4) dissemination. The exploratory stage used a qualitative descriptive approach. Data collection was done through document study, observation, interview, and questionnaire. Data analysis technique used was interactive analysis model. Model testing was done through experimental research. The results of this research were: (1) exploration stage showed that Indonesian literature textbook used in Public Elementary School 15, Public Elementary School 02 Kleco, and Public Elementary School 2 Sumber Surakarta had not been in accordance with the students' and teachers' needs, (2) Indonesian textbook was developed through preliminary field testing; and (3) model testing phase was done through experimental research in the main field testing. The value of $\mathrm{t}_{\text {obtained }}(0.43)$ was then consulted to the value of $\mathrm{t}_{\text {table }}\left(\right.$ with $_{\mathrm{N}}=90, \alpha$ $=0.05)$ which was 1.64 so critical area $\{\mathrm{t}<-1.64$ or $\mathrm{t}>1.64\}$. It could be concluded that $\mathrm{t}_{\text {obtained }}(0.43)<\mathrm{t}_{\text {table }}$, as a result, $\mathrm{H}_{0}$ was accepted and the research was stated significant. In conclusion, Indonesian textbook with character education was effective to improve students' receptive skills.
\end{abstract}

Keywords: textbook, Indonesian language, character education, active learning, ICT

\section{Introduction}

The less successful phenomenon of Indonesian language learning in four most dominant elementary schools grade V in Surakarta was due to the students' low receptive skill level. This was because of, among other reasons, the limitation of textbook as a reference. The existing or commonly used reference books had not fully supported the success of Indonesian language learning in this case the students' receptive skills. According to [1] Mustari, the planting of character values is a fundamental effort to improve the quality of character that must be owned by the nation's current and future generations. The character values that are developed are based on 18 indicators, they are religious, honesty, tolerance, discipline, hard work, independent, creative, democratic, curiosity, spirit of nationality, love of the country, appreciate achievement, friendly, peaceful, reading habit, care of the environment, care of the social condition, responsibility. In order to implement the values of these characters in learning, it could be done through the development of an Indonesian textbook characterized by character education for elementary school students.

Ulum in his research concluded that important character education was instilled to equip learners independently [2]. According to Asma, the values of the characters included religious values, social norms, rules or laws, academic ethics and human rights principles, grouped into five main values, namely: the values of hu- man behavior to God, to himself, to fellow human beings, to the environment, and to the nationality [3]. The noble values contained in the customs and cultures of our tribes, have been studied and summarized. Based on the study, it has been identified the noble values that are internalized to the nation generation through character education. The values are: religious, honesty, discipline, hard work, creative, independent, friendly, peace loving, caring, and responsibility.

Active learning is activities that help students to test their feelings, values, and behaviors [4]. Silberman describes that in active learning, students do a lot of activities. They use their brains to learn ideas, solve problems, and apply what they have learnt. According to Lorenzen, active learning is a method in educating or inviting students to participate actively in the classroom [5]. Active learning aims to optimize the use of all potential possessed by students, so that all students can achieve satisfactory learning outcomes according to their personal characteristics. Therefore, learning to write theater script needs to be done through active learning [6]. According to Cherney reveals that the application of active learning depends on the level of the program, the material, the type of student, the type of class, as well as the discussion required by the students to improve the understanding of the material [7]. The application of active learning is needed to improve the theater script writing skill. The results of research conducted by Meyers \& Jones concluded that by applying active learning strategies, students can express four language skills: listening, speaking, 
reading, and writing [8]. Afterwords, they also mentioned that the use of active learning could also improve both reseptive and productive skill.

According to Prince's research concluded that the selection of active learning strategy in learning is an appropriate consideration to make learning effective [9]. Active learning is an effective teaching technique compared to conventional teaching techniques. The advantages of active learning are: (1) students will learn more material; (2) the student may keep the information longer; and (3) students like learning, faculty, and class conditions more as something new and variative. Active learning allows students to study in the classroom with the help of lecturers or without lecturers, and other students.

Learning resources are not just reference books or textbooks Sudjana revealed that learning resources are all resources that can be utilized in the interest of teaching and learning, either directly or indirectly, in whole or in part [10]. Furthermore, he said that learning resources can be divided into two parts, namely (1) learning resources designed or deliberately created and used to shape teaching and learning and (2) learning resources that are not specifically designed but can be used to facilitate learning.

Literature can develop students' insights and knowledge into humanly behavior. Literature reflects real life. Literature exudes all that is good and meaningful in human experience. Through his association with literature, students will gain value for their development, namely (1) language development, (2) cognitive development, (3) personality development, (4) social development, (5) physical development, (6) moral development, and (7) conceptual growth in the story [11].

The results of research by Culinan concluded that listening and reading good stories can help improve vocabulary, sharpen sensitivity to language, and expand language usage in the style of writing [12]. In addition, research on the use of children's literature as a source of learning to read has been done by Katleen Graham a librarian from the South Australian Education Department. The result was that after six months most children increased their language skills according to their chronological age and earned an equivalent value as four years of reading [13].

Based on the results of the exploratory stage study, students and teachers need Indonesian textbooks which is focused on Receptive Skills. During this time, Indonesian receptive skills materials were not understood by the teacher and there was no supporting books. Indonesian textbooks on Receptive skills were expected to support the success of learners in learning Indonesian. The receptive skills of learners can increase if an Indonesian receptive skills textbook with character education is available [14]. A good textbook mus meet the following standards: (1) in accordance with the basic competence and standards competence established by BSNP; (2) covers the time span of its use; (3) includes the capital, metropolis, and regional authors; (4) in accordance with the principles of multiculturalism; and (5) easy to be understood [15]. Textbook contains specific materials used as a teaching and learning guide at school [16]. Textbooks are usually used in conjunction with other learning resources such as workbooks, teacher reference books or supporting textbooks [17]. In order to fulfill the need of Indonesian receptive skill textbook, this research is urgently needeed to be done in Surakarta Elementary School, Central Java. rules of Indonesian language.

\section{Methodology}

This research was conducted by following the flow of research and development procedures (R and D) [18]. Furthermore, Borg and Gall argued that research and development is a process used to develop and validate educational products. Seals and Richey stated that research and development as a systematic review of the design, development and evaluation of programs, processes and learning products that must meet the criteria of validity, practicali- ty, and effectiveness [19]. In line with this, Plomp added the criteria "can show aditional value"[20].

There are 10 steps of research and development, they are: (1) exploration study, (2) planning, (3) design development, (4) preliminary field test, 5) revision of limited field test results, (6) main field test, (7) revision of main field test result, (8) feasibility test, (9) final revision of feasibility test, (10) dissemination and implementation of final product [21]. The ten steps are summarized into 4 main stages, each of which includes several operational steps. The four steps are; (1) the exploration stage, (2) the model development stage, (3) the model testing stage, and (4) the dissemination and implementation of the model stage [22],[23].

\section{Results and Discussion}

Based on the findings at the exploration stage, it could be concluded that there was a problem in Indonesian learning process in the Elementary Schools grade 5. The problems were (1) the absence of Indonesian Education textbook with character education, (2) there was no action to improve the students' receptive ability, (3) the teachers did not understand the receptive ability materials, and (4) teachers had not used innovative learning models yet. In principle, students, teachers, and policy makers agreed that the Indonesian Education textbook with character education needed to be developed immediately. Furthermore, based on the analysis of the students' and teachers' need, the following results were obtained (1) Indonesian Education textbook with character education should be prepared to facilitate and guide students to improve the receptive ability, (2) innovative learning procedures (active learning) was necessary to apply as a solution to the students' saturation in monotonous and non-varied learnings, and (3) the textbook could help the teachers in understanding receptive skill as learning resources and (4) the need of literature as learning resources that can help improving the the students' receptive skills.

Based on the findings at the exploratory stage, there were six things to be done, they were: (1) developing prototype into textbook model of Indonesian Education with character education, (2) validating prototype development model through expert judgment, (3) validating the model through limited trial, (4) validating the model through broader trials, (5) deciding the final textbook models, and (6) concluding the development result.

\section{Description of Research Data}

This research data was in a form of the students' receptive skill score of Elementary Schools in Surakarta which was used as research sample, both for experimental class and control class. In the experimental class there were 90 respondents who come from the students of Public Elementary School 15 Surakarta grade 5. They were treated by using Indonesian Education textbook model with character education. On the contrary, there were 85 respondents from the control class who came from the Public Elementary School 02 Kleco grade 5 who were treated by using the old textbook model.

Referring to the above explanation, the total number of respondents was 165 , ie 90 respondents in the experimental class, and 75 other respondents in the control class. In the experimental and control classes, all respondents were given test on the receptive ability before tratment (pre-test) and after treatment (post-test). Based on the above description, the description of research data was grouped into 4 (four), they were: (1) pre-test score data on the students' receptive ability in the experimental class; (2) post-test score data on the students' receptive ability in the experimental class; (3) pre-test score data on the students' receptive ability in the control class; and (4) post-test score data on the students' receptive ability in the control class. Each study data group would describe its statistical quantities that include: (1) the calculation of central tendencies, such as: mean, median, mode (2) the calculation of the spread tendency, such as: variance, and 
standard deviation; (3) the highest score; (4) the lowest score; (5) range; (6) the result of frequency distribution; and (7) the histogram image of the frequency score.

\section{a. Pre-test Score Data of the Experimental Class}

Based on the descriptive analysis conducted with Excel 2013 program, the pre-test score of 90 students of Public Elementary School 15 Surakarta grade 5 as the experiment class could be reported: $(1)$ central tendency: mean $=39.22$, mode $=35$, and median $=37 ;$ (2) spread tendency: variance $=51.97$, and standard deviation $=7.21 ;(3)$ the highest score $=55$; and the lowest score $=$ 26 ; (4) range $=29$.

Frequency distribution of pre-test score of students' receptive skill was obtained through calculation steps as follows: (1) determine the range, ie by reducing the highest score with the lowest score: $55-26=29$; (2) determine the number of interval classes. In this study 5 interval classes were used; (3) determine the length of the interval class by dividing range by number of interval classes; 29 : $5=5.8$ which then rounded to $6 ;(4)$ choose the lower end of the first interval class. This was done by taking the lowest score. Therefore, the first interval class starts from 26. Based on the steps of preparing the frequency distribution, the frequency distribution of the pre-test score of the students' receptive ability could be seen in Table 1.

Table 1.: pre-test score frequency distribution of the experiment class

\begin{tabular}{ccc}
\multicolumn{2}{c}{ Table 1.: pre-test score frequency distribution of the experiment class } \\
\hline Interval Class & $\begin{array}{c}\text { absolute frequency (f } \\
\text { abs) }\end{array}$ & $\begin{array}{c}\text { relative frequency } \\
(\boldsymbol{\%})\left(\mathbf{f}_{\text {rel }}\right)\end{array}$ \\
\hline $26-31$ & 12 & 13,33 \\
\hline $32-37$ & 34 & 37,78 \\
\hline $38-43$ & 21 & 23,33 \\
\hline $44-49$ & 11 & 12,23 \\
\hline $50-55$ & 12 & 13,33 \\
\hline Total & 90 & 100,00 \\
\hline & &
\end{tabular}

\section{b. Post-test Score Data of Experimental Class}

Based on the descriptive analysis conducted with Excel 2013 program, the post-test score of 90 students of Public Elementary School 15 Surakarta grade 5 as the experiment class could be reported: $(1)$ central tendency: mean $=82.50$, mode $=82$, and median $=82 ;$; 2 ) spread tendency: variance $=36.97$, and standard deviation $=6.08 ;$; $(3)$ the highest score $=95$; and the lowest score $=$ 70 ; (4) range $=25$. As the stages of preparing the frequency distribution of the pre-test scores described above, the same calculation was done to the post-test data. The result was: (1) range $=95-70=25 ;$ (2) number of interval classes were set 5 ; (3) the interval class length $25: 5=5$ however, it wes then set to 6 to make sure that all of the data could be inputed in the class interval; and (4) the lower end of the first interval class starts from the smallest data of 70. Based on the above calculation, the frequency distribution of the post-test score of the students' receptive ability could be seen in Table 2 .

Table 2. Frequency Distribution of the post-test score in the experiment class

\begin{tabular}{ccc}
\hline Interval Class & $\begin{array}{c}\text { absolute } \\
\text { frequency }\left(\mathbf{f}_{\text {abs }}\right)\end{array}$ & $\begin{array}{c}\text { relative } \\
\text { frequency }\left(\boldsymbol{\%}_{\mathbf{0}}\right)\left(\mathbf{f}_{\text {rel }}\right)\end{array}$ \\
\hline $70-75$ & 9 & 10,00 \\
\hline $76-81$ & 28 & 31,11 \\
\hline $82-87$ & 37 & 41,11 \\
\hline $88-93$ & 10 & 11,11 \\
\hline $94-99$ & 6 & 6,67 \\
\hline Total & 90 & 100,00 \\
\hline
\end{tabular}

\section{c. Pre-test Score Data of the Control Class}

Based on the descriptive analysis conducted with Excel 2013 program, the pre-test score of 75 students of Public Elementary School 02 Kleco grade 5 as the control class could be reported: (1) central tendency: mean $=40.15$, mode $=38$, and median $=39 ;(2)$ spread tendency: variance $=51.88$, and standard deviation $=7.20$;
(3) the highest score $=55$; and the lowest score $=26$; (4) range $=$ 29 . The preparation of the frequency distribution of the control class pre-test scores data obtained: (1) range $=55-26=29$; (2) number of interval classes were set 5 ; (3) the interval class length $29: 5=5.8$ which was rounded into 6 ; and (4) the lower end of the first interval class starts from the smallest data of 26 . Based on the above calculation, the frequency distribution of the pre-test score of the students' receptive ability could be seen in Table 3 .

Table 3. frequency distribution of the pre-test score in the control class

\begin{tabular}{ccc}
\hline Interval Class & $\begin{array}{c}\text { absolute frequency (f } \\
\text { abs })\end{array}$ & $\begin{array}{c}\text { relative frequency } \\
(\boldsymbol{\%})\left(\mathbf{f}_{\text {rel. }}\right)\end{array}$ \\
\hline $26-31$ & 6 & 8,00 \\
\hline $32-37$ & 22 & 29,33 \\
\hline $38-43$ & 25 & 33,33 \\
\hline $44-49$ & 11 & 14,67 \\
\hline $50-55$ & 11 & 14,67 \\
\hline Total & 75 & 100,00
\end{tabular}

\section{d. Post-test Score Data of the Control Class}

Based on the descriptive analysis conducted with Excel 2013 program, the post-test score of 75 students of Public Elementary School 02 Kleco grade 5 as the control class could be reported: (1) central tendency: mean $=62.67$, mode $=63$, and median $=63 ;(2)$ spread tendency: variance $=69.04$, and standard deviation $=8.31$; (3) the highest score $=78$; and the lowest score $=43$; (4) range $=$ 35 . The preparation of the frequency distribution of the control class post-test scores data obtained: (1) range $=78-43=35$; (2) number of interval classes were set 5 ; (3) the interval class length $35: 5=7$ however, it wes then set to 8 to make sure that all of the data could be inputed in the class interval; and (4) the lower end of the first interval class starts from the smallest data of 43 . Based on the above calculation, the frequency distribution of the post-test score of the students' receptive ability could be seen in Table 4 .

Table 4. Frequency Distribution of the post-test score in the control class

\begin{tabular}{ccc}
\hline Interval Class & $\begin{array}{l}\text { absolute frequency }(\mathbf{f} \\
\text { abs })\end{array}$ & $\begin{array}{l}\text { relative } \\
(\%)\left(\mathbf{f}_{\text {rel. }}\right)\end{array}$ \\
\hline $43-50$ & 6 & 8,00 \\
\hline $51-58$ & 10 & 13,33 \\
\hline $59-66$ & 36 & 48,00 \\
\hline $69-74$ & 17 & 22,67 \\
\hline $75-82$ & 6 & 8,00 \\
\hline Total & 75 & 100,00 \\
\hline
\end{tabular}

\section{Requirement Analysis Testing}

The inferencial data analysis to profen that the research hypothesis was accepted or rejected used independent t-test. This statistical data analysis needs to meet several requirement analysis; they are: (1) normality test, (2) homogeneity test, and (3) balance test. Normality test was done using lilliefors technique, while homoeneity of variance test was done using Bartlett's analysis, and the balance test was done using independent $t$-test.

\section{a. Normality Test}

As mentioned in the above statements, the data tested by normality in this research were two: (1) pre-test post-test score data of students' receptive skill in experiment group, and (2) pretest post-test score data of students' receptive skill in in the control group. Here are the normality test results for both groups of data above.

Normality test for pre-test post-test deviation score data of experimental class

Normality test toward pre-test post-test deviation score data in experimental class showed maximum $L_{o}$ of 0.0534 . From the list of chritical $\mathrm{L}$ for Lilliefors test with $\mathrm{n}=90$ and real level $\alpha=0.05$, it is obtained $L_{t}=0.0934$. from the above comparison, it could be stated that $L_{o}$ was smaller than $L_{t}$, thus it could be stated that the pre-test post-test deviation score data of the experiment class came from population with normal distribution. 


\section{Normality test for pre-test post-test deviation score data of control class}

Normality test toward pre-test post-test deviation score data in control class showed maximum $L_{o}$ of 0.0655 . From the list of chritical L for Lilliefors test with $\mathrm{n}=75$ and real level $\alpha=0.05$, it is obtained $L_{t}=0.1023$. from the above comparison, it could be stated that $L_{o}$ was smaller than $L_{t}$, thus it could be stated that the pre-test post-test deviation score data of the experiment class came from population with normal distribution.

\section{b. Homogeneity of Variance Test}

This homogeneity of variance test was conducted to test the similarity of variance between pre-test post-test score of students' receptive skill in experimental group and control group. The statistical technique used for this purpose is by Bartlett's test technique. This test was intended to test the null hypothesis $\left(\mathrm{H}_{0}\right)$ which stated that the variance of pre-test post-test score between experimental class and control class was homogeneous on the real level $\alpha=0.05$ against the alternative hypothesis $\left(\mathrm{H}_{1}\right)$ which stated that between the variance of pre-test post-test score of the experimental class and the control class was not homogeneous at the same real level. The test criterion used was that $\mathrm{H}_{0}$ is rejected if it turns out that $\chi_{\text {obtained is smaller or equal to }}^{2} \chi_{\text {table }}^{2}$ at the real level $\alpha=0.05$. Conversely, if $\chi_{\text {obtained is higher than }}^{2} \chi_{\text {table }}^{2}$ at the real level $\alpha=0.05$, then $\mathrm{H}_{0}$ was accepted which means that the variance score was homogenous.

Homogeneity test between variance of pre-test post-test enumeration score of students' receptive skill in the experimental group and the control group resulted in $\chi_{\text {obtained }}^{2}=11.14$. From the chi-squared distribution table with $\mathrm{df}$ (degrees of freedom) 1 and the real level $\alpha=0.05$ obtained $\chi_{\text {table }}^{2}=38.4$ which was much larger than $\chi_{\text {obtained }}^{2}$. Thus, based on the testing criterion, the null hypothesis $\left(\mathrm{H}_{0}\right)$ which stated that the variance of pre-tes post-test score of the students' receptive ability in the experimental group and the control group was homogenous was accepted. The conclusion was that the variance of pre-test post-test score deviation in the students' receptive ability in both groups was homogeneous.

\section{c. Balance Test}

The balance test aims to test the average equation of students receptive skill between the experimental group and the control group. The statistical test used is t-test with the real level $\alpha=0.05$. Hypothesis proposed: $\mathrm{H}_{0}$ if $\mathrm{t}_{\mathrm{obtained}}>\mathrm{t}_{\text {table }}$ then the students variance score of the receptive ability of both groups are not balanced. $\mathrm{H}_{1}$ if the $\mathrm{t}_{\mathrm{obtained}}<\mathrm{t}_{\text {tabel }}$ then the students' variance scores of both groups were balanced. The test result showed that $t_{\text {obtained }}$ $=1.02<$ ttabel $=1.67$. It could be concluded that the average score of the students' receptive ability of experimental group and the control group was balanced.

\section{Hypothesis Testing}

Hypothesis testing here means to know whether the proposed null hypothesis $\left(\mathrm{H}_{0}\right)$ is rejected, or vice versa at certain level of confidence the proposed alternative hypothesis $\left(\mathrm{H}_{1}\right)$ is accepted. In accordance with those mentioned in the previous section, the research hypotheses was tested by independent t-test technique. The technique of statistical analysis was used to observe the effectiveness of the treatment in the use of the textbook model, with those who did not use the textbook model. The effectiveness of the textbook model to improve the receptive ability of Elementary School Students grade 5 in Surakarta was tested.

Based on statistical analysis with independent t-test technique, it showed that $\mathrm{t}$-obtained was 0.43 . Meanwhile, the critical area: $\mathrm{t}$
(0.05: 163) $=1.64$ so critical area: $\{\mathrm{t}<-1.64$ or $\mathrm{t}>1.64\}$. It could be seen that and $\mathrm{t}_{\text {obtained }}=0.43<\mathrm{t}_{\text {table }}$ so $\mathrm{H}_{0}$ was accepted. Thus, there was a significant difference between the receptive ability of students who were taught using the textbook model with students who were taught using the used textbook. In other words, there were significant difference between the students' receptive skill for those who used Indonesian Education textbook with character education through active learning using literature as a learning resources compared with those who used the government textbook The implementation of active learning is very supportive on theater education learning to improve the receptive ability optimally. Cherney concluded that the application of active learning was based on the level of the program, the material, the type of students, the type of class, and the discussion required by the students to improve the understanding of the material [24]. The application of active learning is needed to improve the understanding of the material in this case is the receptive skill. Meyers \& Jones concluded that by the application of active learning strategies, students could express four language skills, they are listening, speaking, reading, and writing [25]. Katleen Graham research showed that the use of children literature as the learning resources for six months could improve the students' language competencies as their chronological ages [26]. Thus, the application of active learning in the Indonesian Language learning by using literature as the learning resources was effective to improve the students' receptive ability.

\section{Conclusion}

The exploratory stage showed that Indonesian literature textbook recently used in the Public Elementary School 15 Surakarta, Public Elementary School $02 \mathrm{Kleco}$, and Public Elementary School 2 Sumber, Surakarta has not meet the students' and teachers' need. The model development stage produced Indonesian literature textbook using ICT learning based through preliminary field testing. Testing the effectiveness of the textbook model was done through main field testing. The value of $t_{\text {obtained }}$ was 0.43 meanwhile the critical area: $\mathrm{t}_{(0.05: 163)}=1.64$; $\mathrm{ca}\{\mathrm{t}<-1,64$ or $\mathrm{t}>1.64\}$ thus $\mathrm{t}_{\text {obtained }}(0.43)<$ ca so Ho: $\mu 1 \neq \mu 2$ was accepted. The Indonesian literature textbook with character education effectively improve the students' receptive skill. The textbook could be accepted by teachers, policy makers, and students as teaching materials.

\section{References}

[1] Mustari, Nilai Karakter untuk Refleksi Pendidikan, Jakarta: Raja Grafindo Persada, 2014.

[2] W. M. Ulum, 2014. "Pengembangan Buku Teks Membaca Intensif Berbasis Karakter di Sekolah Dasar", Jurnal Pendidikan Humaniora, vol. 2 no. 2, pp. 130-134, 2014

[3] J. M. Asma, Buku Panduan Internalisasi Pendidikan Karakter di Sekolah Dasar, Yogyakarta: Diva Press, 2014.

[4] M. L. Silberman, Active Learning 101 Cara Bealajar Siswa Aktif, Bandung: Nuansa, 2006.

[5] M. Lorenzen, Active Learning and Library Instruction (online) dalam http://www.libraryinstruction.com/link.html, 2001.

[6] K. Saddhono, "Integrating Culture in Indonesian Language Learning for Foreign Speakers at Indonesian Universities", Journal of Language and Literature, vol. 6 no.2, pp. 349-353, 2015.

[7] I. D. Cherney, "The Effects of Active Learning on Student' Memories for Course Content", Journal of Active Learning in Higher Education, vol. 9 no.. 2, pp. 152-171, 2008.

[8] C. Meyers and T. B. Jones, Promoting Active Learning, San Fransisco: Jossey-Bass Publisher, 1993.

[9] M. Prince, "Does Active Learning Work: a Review of the Recearch", Journal Engr. Education, vol. 93 no. 3, pp. 223-2231, 2004.

[10] N. Sudjana, Penilaian Hasil Proses Belajar Mengajar. Cetakan ketujuh, Bandung: PT Remaja Rosdakarya, 2003. 
[11] K. Saddhono, "Cultural and social change of foreign students in Indonesia: The influence of Javanese Culture in Teaching Indonesian to Speakers of Other Languages (TISOL)", IOP Conference Series: Earth and Environmental Science, vol. 126. no. 1, pp. 1-8, 2018.

[12] B. E. Culinan, Literature for Young Children, Strickland and Morrow (Eds.). Emerging Literacy Young Children to Read and Write, Delaware: International Reading Association, 1989.

[13] J. Hancoek and C. Leaver, Major Teaching Strategies for English, Victoria: Australian Reading Association, 1994.

[14] K. Saddhono, "The Argumentative Writing Skill with Multicultural Awareness in Indonesian Language for Foreign Learners", Ponte International Scientific Researches Journal, vol. 72 no. 4, pp. 108116, 2016

[15] S. D. Djanali, Pengembangan Inovasi Pendidikan. Jakarta: Ditjen Dikti Depdiknas, 2007.

[16] J. C. Richard and T. Rodgers, Approaches and Methods in Language Teaching, Cambridge: Cambridge University Press, 2002

[17] B. Tomlinson and Masuhara (Eds), Developing Language Course Materials. Singapore: RELC Portfolio Series, 2008.

[18] M. D. Gall and W.R Borg, Educational research: An introduction 8 2007.

[19] B. B. Seels and R. Richey, Teknologi Pembelajaran: Definisi dan Kawasannya. Penerjemah Dewi S. Prawiradilaga dkk. Jakarta: Kerjasama IPTPI LPTK UNJ, 1994.

[20] Tj. Plomp, "Educational Design: Introduction", in Tjeerd Plomp (ed). Educational \& Training Systen Desing: Introduction Desing of Education and Training. Utrecht: Lemma. Nederlands. Faculty of Educational Science and Technology, University of Twente, 1999.

[21] . M. D. Gall and W.R Borg, Educational research: An introduction 82007.

[22] N. S. Sukmadinata, Metode Penelitian Pendidikan, Bandung: Remaja Rosdakarya, 2010.

[23] J. Nurkamto, "Struktur Penelitian dan Penulisan R \& D Bidang Pendidikan (Versi Borg dan Gall)", Makalah Kuliah Umum Program Pascasarjana IKIP PGRI Madiun, 30 September 2012.

[24] I. D. Cherney, "The Effects of Active Learning on Student' Memories for Course Content", Journal of Active Learning in Higher Education, vol. 9 no.. 2, pp. 152-171, 2008.

[25] C. Meyers and T. B. Jones, Promoting Active Learning, San Fransisco: Jossey-Bass Publisher, 1993.

[26] J. Hancoek and C. Leaver, Major Teaching Strategies for English Victoria: Australian Reading Association, 1994. 